\title{
Associations of Autoimmunity, Immunodeficiency, Lymphomagenesis, and Gut Microbiota in Mice with Knockins for a Pathogenic Autoantibody
}

Shweta Jain, ${ }^{*}$ Jerrold M. Ward, ${ }^{*}$ Dong-Mi Shin, ${ }^{\dagger}$ Hongsheng Wang, ${ }^{*}$ Zohreh Naghashfar, ${ }^{*}$ Alexander L. Kovalchuk, ${ }^{*}$ and Herbert C. Morse III*

From the Virology and Cellular Immunology Section, * Laboratory of Immunogenetics, National Institute of Allergy and Infectious Diseases, NIH, Rockville, Maryland; and the Department of Food and Nutrition, ${ }^{\dagger}$ Seoul National University, Seoul, Republic of Korea

Accepted for publication

May 9, 2017.

Address correspondence to Herbert C. Morse III, M.D. 5640 Fishers Ln, Rockville, MD 20852. E-mail: hmorse niaid.nih.gov.

\begin{abstract}
A number of mouse strains transgenic for B-cell receptors specific for nucleic acids or other autoantigens have been generated to understand how autoreactive $B$ cells are regulated in normal and autoimmune mice. Previous studies of nonautoimmune $\mathrm{C} 57 \mathrm{BL} / 6$ mice heterozygous for both the $\mathrm{IgH}$ and IgL knockins of the polyreactive autoantibody, 564, produced high levels of autoantibodies in a largely Toll-like receptor 7-dependent manner. Herein, we describe studies of mice homozygous for the knockins that also expressed high levels of autoantibodies but, unlike the heterozygotes, exhibited a high incidence of mature B-cell lymphomas and enhanced susceptibility to bacterial infections. Microarray analyses and serological studies suggested that lymphomagenesis might be related to chronic B-cell activation promoted by IL-21. Strikingly, mice treated continuously with antibioticsupplemented water did not develop lymphomas or abscesses and exhibited less autoimmunity. This mouse model may help us understand the reasons for enhanced susceptibility to lymphoma development exhibited by humans with a variety of autoimmune diseases, such as Sjögren syndrome, systemic lupus erythematosus, and highly active rheumatoid arthritis. (Am J Pathol 2017, 187: 2020-2033; http://dx.doi.org/10.1016/j.ajpath.2017.05.017)
\end{abstract}

Systemic lupus erythematosus (SLE) is a severe, multigenic autoimmune disease associated with high serum levels of a variety of autoantibodies directed to nucleic acids and selfantigens. Immune complexes formed by autoantibodies and their targets are deposited in glomeruli, frequently resulting in lethal renal impairment. A number of efforts to understand this pathology have used mouse strains expressing immunoglobulin transgenes with B-cell receptor (BCR) specificities for nucleic acids or other antigens recognized by autoantibodies from patients with SLE. ${ }^{1}$ One of these mouse strains, termed 564Igi, bears targeted insertions of the heavy $\left(\mathrm{V}_{\mathrm{H}} \mathrm{D}_{\mathrm{H}} \mathrm{J}_{\mathrm{H}}\right)$ and light $\left(\mathrm{V} \kappa \mathrm{J}_{\kappa}\right)$ chain genes of the pathogenic autoantibody 564 that reacts with singlestranded DNA, single-stranded RNA, and nucleosomes when expressed on a nonautoimmune C57BL/6 (B6) background. $^{2-4}$
Recent studies focused on 564Igi mice heterozygous for the 564 heavy and light chain insertions at both loci, that we will term $564^{+/-}$mice, showed that B cells from these mice underwent receptor editing, failed to respond to BCR crosslinking or stimulation with lipopolysaccharide, and had large amounts of idiotype-positive serum IgG antibodies, autoantibodies, including antinuclear antibodies (ANAs), and renal disease. Interestingly, production of these antibodies

Supported by the NIH Intramural Research Program (S.J., J.M.W., H.W., Z.N., A.L.K., and H.C.M.), the National Institute of Allergy and Infectious Diseases, Basic Science Research Program (D.-M.S.), a National Research Foundation of Korea grant, and the Ministry of Science, ICT and Future Planning (NRF-2013R1A1A1007858).

Disclosures: None declared.

Current address of S.J., Division of Rheumatology, Department of Medicine, Albert Einstein College of Medicine, Bronx, NY. 
Table 1 List of Antibodies Used in Immunohistochemistry, FACS, and ELISA

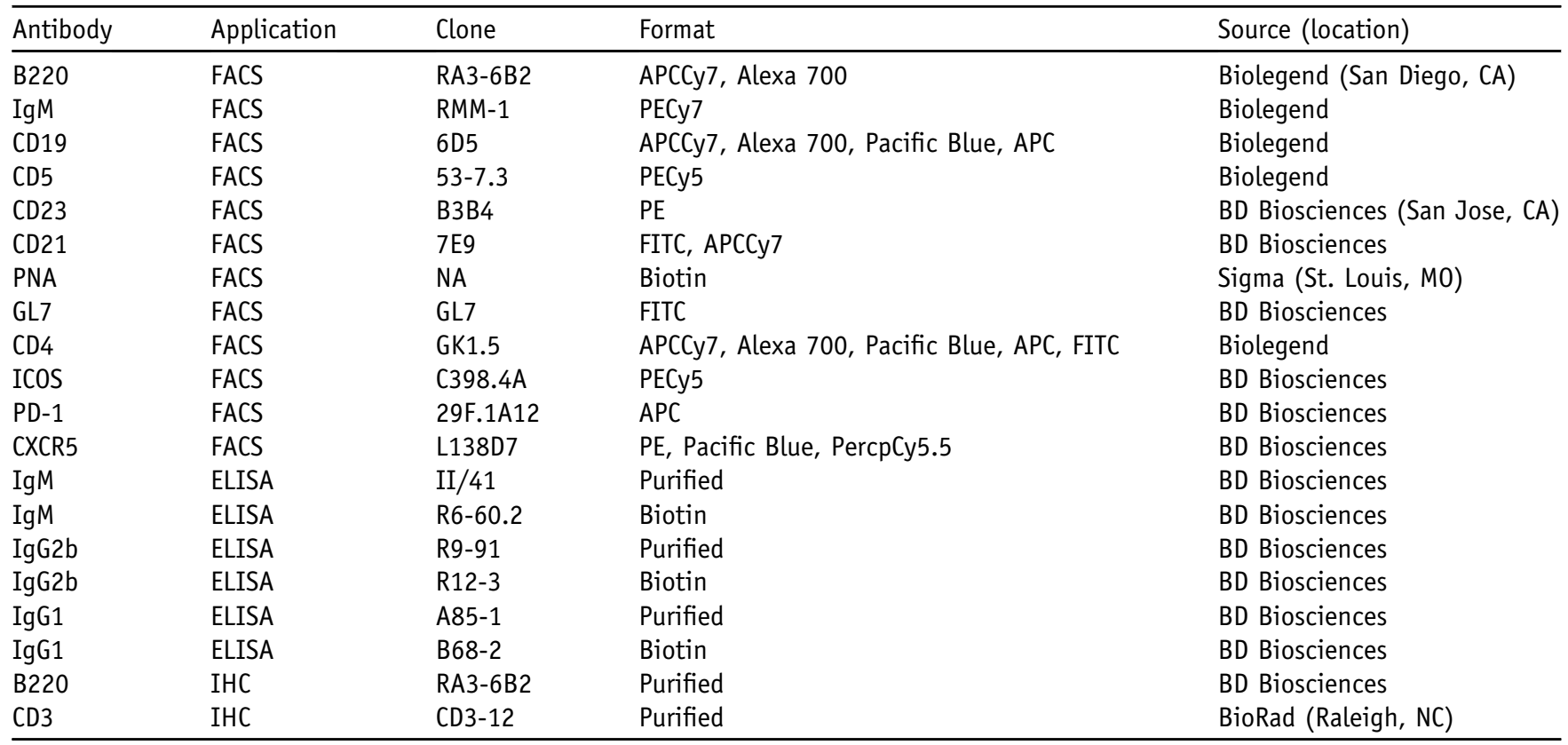

ELISA, enzyme-linked immunosorbent assay; FACS, fluorescence-activated cell sorting; FITC, fluorescein isothiocyanate; ICOS, inducible T cell co-stimulator; IHC, immunohistochemistry; NA, not applicable; PNA, peanut agglutinin.

was largely dependent on Toll-like receptor 7 (TLR7). ${ }^{5}$ The importance of TLR7 to autoimmunity and autoantibody production is also evidenced by strains overexpressing TLR $7^{6-9}$ and inhibition of autoimmune disease by a TLR7 inhibitor. ${ }^{10}$ In addition, it was found that a polymorphism of TLR7 in humans identified by the Genome Wide Association Study is a risk factor for development of SLE. ${ }^{11,12}$

A link between heightened expression of TLR7 and autoimmunity has been associated with high-level expression of the cytokine, IL-21, which is critical to the autoimmune diseases of BXSB.Yaa mice, ${ }^{13}$ type I diabetes mellitus, ${ }^{14}$ autoimmune uveitis, ${ }^{15}$ and collagen-induced arthritis, ${ }^{16}$ among others. Recently, high-level expression of IL-21 was shown to be critical to the development of mature B-cell lineage lymphomas in Swiss Jim Lambert (SJL) mice. ${ }^{17}$ In addition, IL-21 has been associated with the development of a range of human B-cell neoplasms, including Hodgkin disease, ${ }^{18-20}$ multiple myeloma ${ }^{21,22}$ chronic lymphocytic leukemia, ${ }^{23}$ Waldenstrom macroglobulinemia, ${ }^{24}$ and angioimmunoblastic T-cell lymphoma. ${ }^{17,18}$ Finally, increased expression of IL-21 and its receptor, IL-21R, has been documented for autoimmune disorders with increased risk for lymphoma development, including SLE, Sjögren syndrome, and highly active rheumatoid arthritis. ${ }^{25-28}$

Herein, we describe studies of mice homozygous for the 564Igi heavy and light chain insertions that we will term $564^{+/+}$mice. These mice exhibited hypergammaglobulinemia with high levels of serum ANA and anti-double-stranded DNA (dsDNA) antibodies from early in life but had no clinically significant renal pathology. Unexpectedly, the mice developed a high incidence of post-germinal center (GC)
B-cell lymphomas and exhibited increased susceptibility to bacterial infections. Remarkably, mice treated with oral antibiotics to deplete gut flora not only did not develop infections, but were also lymphoma free and had fewer autoimmune manifestations. This model may be useful for further dissecting long-suspected ties between autoimmunity and lymphomagenesis as well as contributions of gut microbiota to lymphomas and autoimmune disease.

\section{Materials and Methods}

\section{Mice}

Breeding pairs of 564Igi mice heterozygous for knockin alleles of the $564 \mathrm{IgH}$ and $\operatorname{IgK}$ (herein termed $564^{+/-}$mice) were obtained from Dr. Theresa Imanishi-Kari (Tufts University, Boston, MA). The $564^{+/-}$mice were crossed to

Table 2 Primer Sequences for Clonality Analysis

\begin{tabular}{ll}
\hline Primer & Sequence \\
\hline$V_{H} J 558$ & $5^{\prime}$-ARGCCTGGGRCTTCAGTGAAG-3' \\
$\mathrm{V}_{\mathrm{H}} 052$ & $5^{\prime}$-CTCACAGAGCCTGTCCATCAC-3' \\
$\mathrm{V}_{\mathrm{H}} 3660$ & $5^{\prime}$-TCTCAGWCTCTGTCYCTCACC-3' \\
$\mathrm{V}_{\mathrm{H}} \mathrm{X} 24$ & $5^{\prime}$-TCTCSAGTCTGGAGGTGGCCTG-3' \\
$\mathrm{V}_{\mathrm{H}} 7183$ & $5^{\prime}$-GTGGAGTCTGGGGGAGGCTTA-3' \\
$\mathrm{V}_{\mathrm{H}} \mathrm{J} 606 / \mathrm{S} 107 / \mathrm{X} 24$ & $5^{\prime}$-WCTGGAGGAGGCTTGGTGCAA-3' \\
$\mathrm{V}_{\mathrm{H}} \mathrm{GAM3}$ & $5^{\prime}$-TGGAGAGACAGTCAAGATCTCC-3' \\
$\mathrm{V}_{\mathrm{H}} 3609$ & $5^{\prime}$-TTCTCTGGGTTTTCACTGAGC-3' \\
$\mathrm{V}_{\mathrm{H}} 10.1$ & $5^{\prime}$-GTCTGGTGRAGGATTGGTGCA-3' \\
$\mathrm{J}_{\mathrm{H}} 4 \mathrm{R}$ & $5^{\prime}$-CTCTCAGCCGGCTCCCTCAGGG-3' \\
\hline
\end{tabular}


Table 3 Histopathological Features of $564^{+/+}$Mice

\begin{tabular}{|c|c|c|c|c|c|}
\hline Age (months) & Pathology number & Sex & Spleen weight $(\mathrm{mg})$ & Spleen & Lymph nodes \\
\hline 2 & 43010 & ND & 200 & $\mathrm{R}+$; small & \\
\hline 2 & 43241 & $\mathrm{~F}$ & 240 & $\mathrm{R}+$; small & His, $\mathrm{PC}+++$ \\
\hline 4 & 43143 & M & 270 & $\mathrm{R}++$; plasmacytoid & Early HR; DLBCL \\
\hline 4 & 43145 & M & 500 & Atrophic & Blasts +++ \\
\hline 6 & 43142 & M & 300 & $\mathrm{R}+++; \mathrm{FL}$ & \\
\hline 8.5 & 42181 & $\mathrm{~F}$ & 300 & $\mathrm{PCL}$ & \\
\hline 9 & 43197 & $\mathrm{~F}$ & 170 & Atrophic & \\
\hline 9 & 43224 & $\mathrm{~F}$ & 410 & $\mathrm{MH}$ & MH \\
\hline 10 & 43179 & M & 4300 & $P C L$ & $P C L$ \\
\hline 10 & 43182 & $\mathrm{~F}$ & 2560 & CBL & $\mathrm{CBL}$ \\
\hline 12 & 43265 & $\mathrm{~F}$ & 550 & $\mathrm{FL}$; early $\mathrm{HA}$; DLBCL & \\
\hline 12 & 43257 & $\mathrm{~F}$ & 2380 & ND & HR DLBCL \\
\hline 12.5 & 43107 & $\mathrm{~F}$ & 2050 & $\mathrm{CBL} ; \mathrm{HS}$ & HR DLBCL \\
\hline 13 & 43250 & $\mathrm{~F}$ & 340 & $\mathrm{R}$ & $\mathrm{MH}$ \\
\hline 13 & 43251 & $\mathrm{~F}$ & 400 & CBL; apoptosis & $\mathrm{CBL}$ \\
\hline 13 & 43252 & $\mathrm{~F}$ & ND & ND & ND \\
\hline 13 & 43275 & $\mathrm{~F}$ & 850 & HR DLBCL & HR DLBCL \\
\hline 13 & 43279 & $\mathrm{~F}$ & 750 & DLBCL & DLBCL \\
\hline 13.5 & 43280 & $\mathrm{~F}$ & 750 & DLBCL & DLBCL \\
\hline 14 & 43266 & $\mathrm{~F}$ & 250 & DLBCL & \\
\hline
\end{tabular}

F, female; $M$, male; + , minimal degree; ++ , mild degree; +++ , moderate degree; ++++ , severe degree; $B D$, bile duct; $C B L$, centroblastic DLBCL; DLBCL, diffuse large B-cell lymphoma; EH, erythroid hyperplasia; FL, follicular B-cell lymphoma; GC, germinal center; GN, glomerulonephritis; HA, histiocyte-associated; His, histiocytosis; HR, histiocyte-rich; HS, histiocytic sarcoma; hyper, hyperplasia; Inflamm, inflammation; $\mathrm{MF}$, myeloid foci; $\mathrm{MH}$, myeloid hyperplasia; ND, not determined; PBL, plasmablastic lymphoma; PC, plasma cells; PCL, plasma cell leukemia; PP, Peyer's patch; R, reactive.

generate mice homozygous for the knockins at both loci (herein termed $564^{+/+}$mice). Some members of the $564^{+/+}$ mouse colony were bred and maintained on water supplemented with $1 \mathrm{mg} / \mathrm{mL}$ ampicillin (Sigma, St. Louis, MO), 1 $\mathrm{mg} / \mathrm{mL}$ metronidazole (Sigma), $1 \mathrm{mg} / \mathrm{mL}$ neomycin (Sigma), and $500 \mu \mathrm{g} / \mathrm{mL}$ vancomycin (Hospira, Lake Forest, IL). The $564^{+/+}, 564^{+/-}$, BXSB.Yaa, and C57BL/6J (B6) control mice (Jackson Laboratory, Bar Harbor, ME) were bred and maintained under specific pathogen-free conditions at the National Institute of Allergy and Infectious Diseases, NIH (Rockville, MD). All mice used in this study were maintained under specific pathogen-free conditions.

\section{Ethics Statement}

Animal care and experimental protocols were approved and performed in compliance with the guidelines stated by the Animal Ethics Committee of the National Institute of
Allergy and Infectious Diseases, NIH. The experimental procedures were in accordance with Animal Study Protocol LIG-16, approved by the Institutional Animal Care and Use Committee of the National Institute of Allergy and Infectious Diseases. Animals developing infections or enlargement of lymph nodes or spleens or otherwise moribund were necropsied after carbon dioxide asphyxiation.

\section{Histopathology and Immunohistochemistry}

At necropsy, selected tissues were either fixed in neutralbuffered formalin or snap frozen for later preparation of RNA and DNA. Sections of paraffin-embedded tissues stained with hematoxylin and eosin were examined microscopically to establish histopathological diagnoses using established criteria. ${ }^{29-31}$ Slides were stained with antibodies specific for B220 (CD45R), CD3, and F4/80 using antibodies listed in Table 1. Histopathology images were 
Table 3 (continued)

\begin{tabular}{|c|c|c|c|c|c|c|}
\hline Lung & Kidney & Liver & Intestine/PP & Peritoneum & Thymus & Other \\
\hline & Negative & Degenerated & & & Atrophic & \\
\hline $\mathrm{R}$ & $\mathrm{GN}+$ & Inflamed & & & Inflamm & \\
\hline Lymph foci & $\mathrm{GN}+$ & BD hyper & & & & \\
\hline Lymph foci & $\mathrm{GN}+$ & Abscesses & Ulcers & & Atrophic & \\
\hline Lymph foci & & FL focus & & & Atrophic & \\
\hline Lymph foci & & Negative & & & & \\
\hline Pneumonia & $\mathrm{GN}+$ & $\mathrm{MH}+++$ & & & Atrophic & \\
\hline PCL cuffs & & & & & PCL medulla & \\
\hline \multirow{3}{*}{ Lymph foci } & & & & & Atrophic & \\
\hline & & HR DLBCL & & & Atrophic & \\
\hline & $\mathrm{GN}+$ & $\mathrm{MH}$ & Focus HR DLBCL & & Mass, medias $\mathrm{CBL}$ & Peritonitis \\
\hline $\mathrm{CBL}+++$ & $\mathrm{GN}+\mathrm{CBL}$ & & & & & \\
\hline ND & ND & ND & & & ND & $\begin{array}{c}\text { Salivary gland abscess, } \\
\text { harderian adenoma }\end{array}$ \\
\hline DLBCL & $\mathrm{GN}+$ & HR DLBCL & & Abscess & HR DLBCL & \\
\hline DLBCL & DLBCL & $\mathrm{DLBCL}++++$ & & & & \\
\hline Lymph foci & DLBCL & Lymph foci & Spironucleus & & & \\
\hline Lymph foci & $\mathrm{GN}+$ & & PP DLBCL & & Atrophic & \\
\hline
\end{tabular}

analyzed with an Olympus microscope model BX41, and photomicrographs were generated with the Olympus digital camera DP71 and cellSens Entry software version 1.11 (Olympus Corp., Tokyo, Japan).

\section{Flow Cytometry (FACS)}

Single-cell suspensions were prepared from spleens and lymph nodes of mice. Red blood cells were lysed, and cells were washed with fluorescence-activated cell sorting (FACS) buffer [Hank's balanced salt solution (GIBCO, Life Technologies, Carlsbad, CA) containing 2\% heatinactivated fetal calf serum (Quality Biologicals, Gaithersburg, MD)]. Cells were stained for FACS analyses following standard procedures. 7-Aminoactinomycin D (Invitrogen, Carlsbad, CA) was added to cells before analysis to exclude dead cells. The antibodies used for staining are listed in Table 1. Samples were acquired using a BD LSRII instrument (BD Biosciences, San Jose, CA) with
FACS Diva software version 8.0 (BD Biosciences) and analyzed using FlowJo software version V_10_CL (Tree Star, Inc., Ashland, OR).

\section{Enzyme-Linked Immunosorbent Assays}

\section{Isotype Enzyme-Linked Immunosorbent Assay}

Serum samples were collected from $564^{+/+}$and control B6 mice, and specific Ig isotypes were quantified. Briefly, serum was diluted (1:1000) and added to plates coated with purified anti-mouse IgG2b, IgM, and IgG1 (BD Biosciences) (Table 1). Respective secondary biotinylated antibodies (BD Biosciences) (Table 1) were then added to the captured specific isotypes, followed by streptavidinhorseradish peroxidase (1:10,000 dilution; Sigma) and tetramethylbenzidine substrate (Invitrogen) for colorimetric estimation. Plates were washed with phosphate-buffered saline-Tween-20 $(0.5 \%)$ at each step. Reactions were stopped using $7 \% \mathrm{H}_{2} \mathrm{SO}_{4}$ (Sigma), and OD was read at 450 
nm using a SpectraMax spectrophotometer (Molecular Devices, Sunnyvale, CA).

\section{Anti-DNA and ANA Enzyme-Linked Immunosorbent Assay}

These estimations were performed using commercial mouse anti-dsDNA antibody total Ig and mouse anti-nuclear antibody total Ig kit (Alpha Diagnostics, Paramus, NJ) following manufacturer's guidelines. Briefly, diluted serum samples (1:100) were added to plates precoated with either purified dsDNA (for anti-DNA quantification) or extractable nuclear antigens (for ANA quantification). Plates were incubated at $37^{\circ} \mathrm{C}$ for an hour and washed with the washing solution provided with the kit, and bound total Ig was detected by horseradish peroxidase-labeled anti-mouse $\operatorname{IgG}+\operatorname{IgM}+\operatorname{Ig} \mathrm{A}(\mathrm{H}+\mathrm{L})$ detection antibody that was also included in the kit. Colorimetric estimation was performed using the tetramethylbenzidine substrate, and reactions were terminated using stop solution. OD was measured at $450 \mathrm{~nm}$ using a SpectraMax spectrophotometer.

\section{Clonality Analysis}

High-molecular-weight genomic DNA was extracted from splenic tissue frozen at necropsy using the Qiagen DNeasy Blood \& Tissue Kit (Qiagen, Germantown, MD), following manufacturer's guidelines. Genomic DNA (100 ng) was used to detect clonal Ig rearrangements using LA PCR Kit version 2.1 (Takara Bio USA Inc, Mountainview, CA). DNA amplification was performed with an initial denaturation at $96^{\circ} \mathrm{C}$ for 3 minutes, followed by 30 cycles of $95^{\circ} \mathrm{C}$ for 15 seconds (template denaturation), $62^{\circ} \mathrm{C}$ for 15 seconds (primer annealing), and $68^{\circ} \mathrm{C}$ for 4 minutes (primer extension) in the first cycle, with a progressive prolongation of the extension time by 20 seconds for subsequent cycles. DNA fragments were gel purified using the Qiagen gel extraction kit and cloned using the TOPO TA kit (Invitrogen). Plasmid DNA was isolated using the Qiagen Plasmid Mini Prep kit and sequenced using the BigDye terminator kit version 1.1 (Applied Biosystems, Foster City, CA). Sequence alignment was performed using the IgBLAST tool (http://www.ncbi. nlm.nih.gov/igblast, last accessed February 23, 2016) or MacVector software version 15.03 (MacVector, Inc., Apex, NC). For amplification of IgH switch junctions, a forward primer annealing at the $\mathrm{IgH}$ intronic enhancer $\left(\mathrm{Em}^{\prime} 1 \mathrm{a}\right)$ paired with reverse primers specific for $\mathrm{Cg} 1, \mathrm{Cg} 2 \mathrm{a}, \mathrm{Cg} 2 \mathrm{~b}$, $\mathrm{Ce}$, and $\mathrm{Ca}$ constant regions were used, as described elsewhere (Table 2). ${ }^{32}$

\section{Microarray}

RNA was prepared from tissues frozen during necropsies using the Qiagen RNAeasy kit. RNA quality and concentration were determined using a Nanodrop ND-1000 spectrophotometer (NanoDrop Technologies, Wilmington, DE). Expression profiling analysis was performed using Agilent National Institute of Allergy and Infectious
Diseases-customized mouse gene expression arrays, and scanned images were analyzed as described previously. ${ }^{33}$ Biological pathway analysis was performed using Ingenuity Pathway Analysis, as described previously. ${ }^{34}$ Differentially expressed genes were identified using one-way analysis of variance with a $5 \%$ false-discovery rate. Data have been deposited in the National Center for Biotechnology Information Gene Expression Omnibus (https://www.ncbi.nlm.nih. gov/geo; accession number GSE96032).

\section{Statistical Analysis}

All data were analyzed using GraphPad Prism software version 7 (Graphpad Software, Inc., La Jolla, CA). Values in the figures represent means \pm SEM for all of the observations. $P$ values were determined by one- or two-way analysis of variance, as appropriate.

\section{Results}

\section{Histopathology Studies of 564Igi Mice}

Most previous studies of mice bearing the $564 \operatorname{Ig}$ heavy $(\operatorname{IgH})$ and $\kappa(\operatorname{Ig} \kappa)$ chain knockins were performed with animals heterozygous for both alleles $\left(564^{+/-}\right)$. We elected to study mice homozygous for both alleles at both loci $\left(564^{+/+}\right)$. During the course of this study, we observed moribund mice as young as 2.5 months of age with no obvious cause of morbidity, whereas others exhibited periorbital infections, splenomegaly, or lymphadenopathy. Fifty-three mice were necropsied, with 30 of the moribund mice listed in Table 3. Histopathology findings revealed that 19 of these mice had hematopoietic neoplasms, mostly affecting spleen and lymph nodes (Table 3). This included 13 diffuse large B-cell lymphomas (DLBCLs), both centroblastic (Figure 1A) and histiocyte rich (data not shown), a histiocytic sarcoma (Figure 1B), three follicular lymphomas, one plasmablastic lymphoma (Figure 1C), two plasma cell leukemias, and one myeloid leukemia (Figure 1D). DLBCLs were positive for B220, as illustrated by a case with Peyer's patch involvement (Figure 1A). Further immunohistochemical analyses revealed striking differences between the distributions of $\mathrm{CD}^{+} \mathrm{T}$ cells and $\mathrm{B} 220^{+} \mathrm{B}$ cells in spleens of a normal mouse (Figure 1E) and a mouse with a DLBCL (Figure 1F). The age at diagnosis for lymphomas ranged from 4 to 14 months, with 14 mice being 10 months of age or older (Table 3). Spleens, almost universally enlarged (normal spleen weight, 90 to 110 $\mathrm{mg}$ ) frequently exhibited significant plasmacytosis, along with myeloid and erythroid hyperplasia in red pulp areas. Lymphoid foci were common in lungs and livers. Atrophic spleens showed loss of follicular structure and often erythro/ myeloid hyperplasia (Supplemental Figure S1A) with typical thymic atrophy (Supplemental Figure S1B).

We also performed clonality analysis of the lymphomas. In general, two types of clonotypic markers are used to assess clonality of mature B-cell lymphomas: a unique VDJ or DJ 

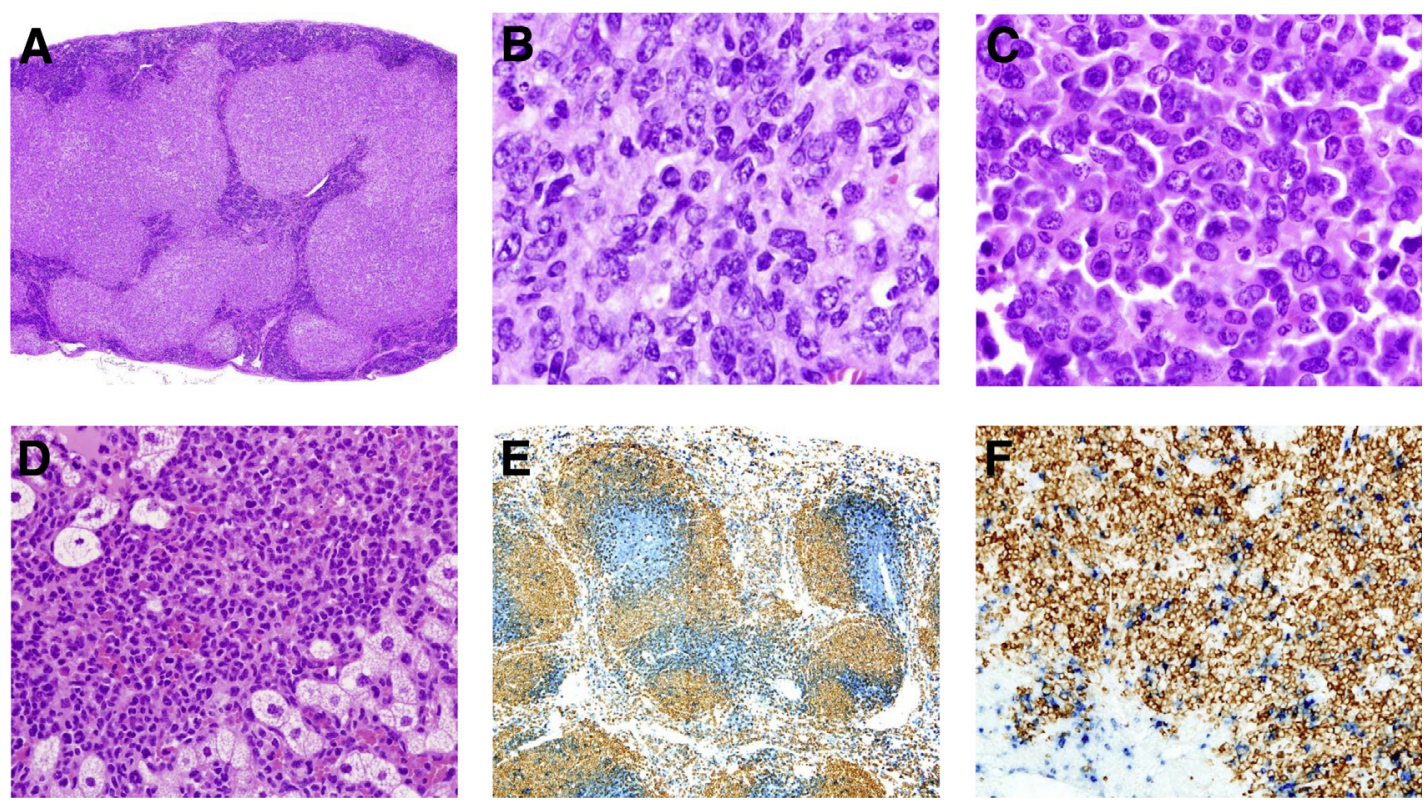

Figure 1 A: Spleen with diffuse large B-cell lymphoma (DLBCL): centroblastic lymphoma showing large white pulp areas with hematoxylin and eosin (H\&E). B: Spleen: histiocyte-rich DLBCL (H\&E). C: Lymph node: plasmablastic lymphoma with immature and more mature plasmacytoid tumor cells (H\&E). D: Myeloid leukemia in liver: immature myeloid forms (H\&E). E: Spleen: immunohistochemical staining depicting B220 (in brown B cells) and CD3 (in blue T cells) on spleen of a normal mouse. F: Spleen with DLBCL: immunohistochemical staining depicting B220 (in brown B cells) and CD3 (in blue T cells) on spleen of a $564^{+/+}$mouse. Original magnification: $\times 4(\mathbf{A}) ; \times 100(\mathbf{B}$ and $\mathbf{C}) ; \times 40(\mathbf{D}) ; \times 10(\mathbf{E}) ; \times 20(\mathbf{F})$.

rearrangement or a switch region junction. Because 564 constructs in these mice already contain rearranged J558.33DST4-JH4, it was difficult to use VDJ rearrangement as a clonotypic marker in this model. Hence, to address the issue of clonality, we performed PCR screening of tumor samples for IgH switch junctions with a forward primer annealing at $\mathrm{E} \mu$ region (Em3'1a) combined with reverse primers specific for $\mathrm{Cg} 1, \mathrm{Cg} 2 \mathrm{a}, \mathrm{Cg} 2 \mathrm{~b}, \mathrm{Ce}$, and $\mathrm{Ca}$ constant regions. Of the 10 cases analyzed, we found that three mice with lymphoblastic lymphomas were negative for switch junctions (potentially non-switched $\mathrm{IgM}^{+}$lymphomas), two mice diagnosed with lymphoblastic lymphomas had two clones each, and one mouse diagnosed with a lymphoblastic lymphoma/plasmablastic lymphoma had two IgG2a clones (Table 4). The presence of these clones was indicative of transformation.
Ten mice were diagnosed with inflammatory lesions, including three with abscesses in the peritoneal cavity, two with periorbital abscesses, one with a salivary gland abscess, and one case of pneumonia. Cases with infections ranged from 2.5 to 14.5 months of age. Examples of a liver abscess and a periorbital infection are shown in Supplemental Figure S1, C and D. One 3-month-old mouse with a peritoneal abscess also had a DLBCL, and a 14-month-old mouse with a periorbital abscess had a coexisting histiocyte-rich DLBCL. No other examples of mice with both disease types were identified. In addition, no B6 control mice in the same age range presented with any signs of infection. More important, bacterial infections were not described for $564^{+/-}$mice.

Previous studies showed that $564^{+/-}$mice had kidney lesions manifested by glomerular deposits of transgene

Table 4 PCR Screening of Tumor Samples in $564^{+/+}$Mice to Detect Transformation

\begin{tabular}{|c|c|c|c|}
\hline Mouse ID & Junction & IgH sequence (forward) & IgH sequence (reverse) \\
\hline $43249-1$ & $5^{\prime} \mathrm{Sm}-\mathrm{Sg} 2 \mathrm{a}$ & 5'-АСТАСАТTСТTGАТСТАСААСТСААTGTGG-3' & $5^{\prime}$-CATCAGGACTGGGGCAGCTGTAGCCAGCAG- $3^{\prime}$ \\
\hline $43249-2$ & $5^{\prime} \mathrm{Sm}-\mathrm{Sg} 2 \mathrm{a}$ & 5'-TCCAAGGTGAGTGTGAGAGGACAGGGGCTG-3' & $5^{\prime}$-AGGATAACCCTGAGCAGACGTGAGTGAGAG-3' \\
\hline $43249-3$ & $5^{\prime} \mathrm{Sm}-\mathrm{Sa}$ & $5^{\prime}$-АTAGAAAАСАСТАСТАСАTTCTTGATCTA-3' & $5^{\prime}$-GGATGAGGTGAACTAGGCTAGAATAGGCTG-3' \\
\hline $43256-1$ & $\mathrm{Sm}-\mathrm{Sa}$ & $5^{\prime}$-CTGAGCTGAGCTGAGCTGAGCTGAGCTGGA-3' & $5^{\prime}-$ AGGAGAGGAGAAGAGAGGAGAGGAGAGGAG- $3^{\prime}$ \\
\hline $43257-1$ & $\mathrm{Sm}-\mathrm{Sg} 2 \mathrm{~b}$ & 5'-CAAAG-G-TAAACTAGGCTGGCTTAACCGATA-3' & $5^{\prime}$-CAGTCCTAA-TAGTTAGGAGGGAGCTGGGAC-3' \\
\hline $43265-1$ & $5^{\prime} \mathrm{Sm}-\mathrm{Sg} 2 \mathrm{~b}$ & $5^{\prime}$-AGTAAGCGAGGCTCTAAAAAACATGGCTGAC-3' & 5'-ATAGGTGGGAGTATTAGGGACTACTCCTAG- $3^{\prime}$ \\
\hline $43273-1$ & $\mathrm{Sm}-\mathrm{Sg} 2 \mathrm{~b}$ & 5'-CTCTGGAGTAGCTGAGATGGGGTGAGATGG-3' & 5'-AGGTAGTACAACTCTGGGTGGGTATCAGGC-3' \\
\hline $43273-2$ & $\mathrm{Sm}-\mathrm{Sg} 2 \mathrm{a}$ & 5'-ACAAGGTTGAGAGCCCTAGTAAGCGAGGCT-3' & 5'-GGGAGCTCAGGTCAGACTTGCATCAAAAAC-3' \\
\hline $43280-1$ & $\mathrm{Sm}-\mathrm{Cg} 2 \mathrm{~b}$ & 5'-CACTGGACTGTTCTGAGCTGAGATGATCTт-3' & 5'-AATGGGAGTGTAAGGGACCAGATTCAGTAA-3' \\
\hline $43280-2$ & $5^{\prime} \mathrm{Sm}-\mathrm{Sa}$ & 5'-ATGAATTTGAAGTTGCCATTAAATGTCCAC-3' & $5^{\prime}$-GGACAGAGACACCGCTCAGATTGAGTCCTC-3' \\
\hline
\end{tabular}

Dashes indicate intraswitch region recombinations; bold, mismatches with germline sequences; underline, microhomology. 
A

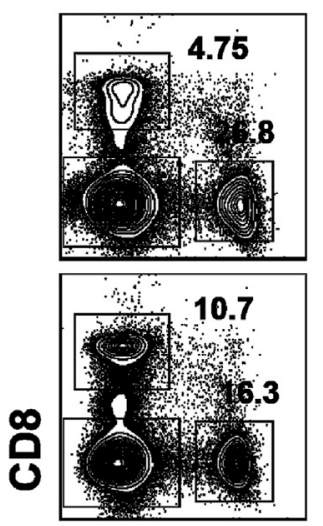

CD4
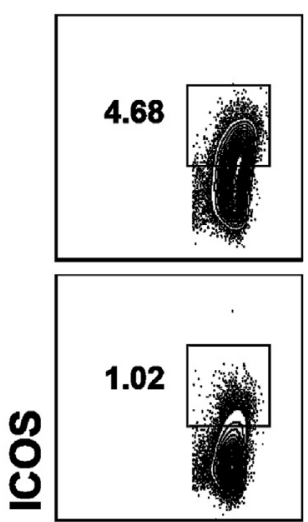

CD4

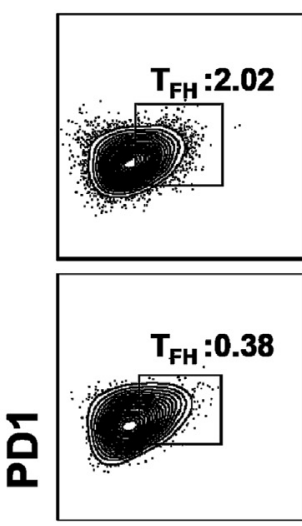

CXCR5
$564^{+/+}$

B6

B

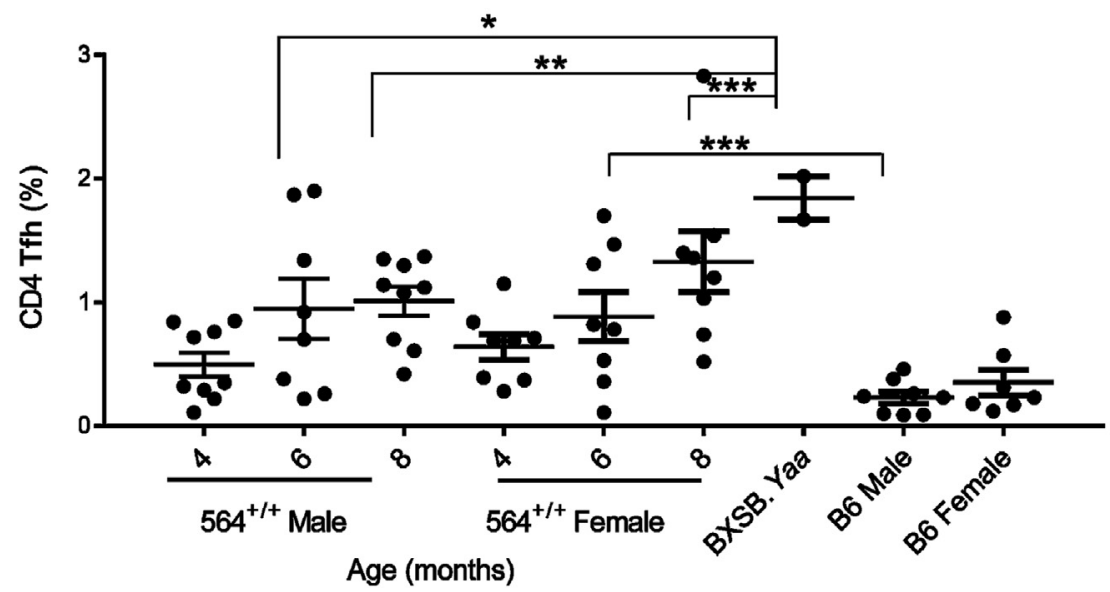

Figure 2 Distribution of Tfh in 564 mice. Splenocytes from male and female $564^{+/+}$( 4 to 8 months), BXSB.Yaa ( 4 months), and male and female C57BL/B6 control mice were stained with antibodies against CD4, CD8, ICOS, PD1, and CXCR5 and analyzed by flow cytometry. A: Live single cells were gated and analyzed for $\mathrm{CD} 4$ Tfh $\left(\mathrm{CD}^{+} \mathrm{ICOS}^{+} \mathrm{PD} 1^{+} \mathrm{CXCR} 5^{+}\right)$. Numbers in the contour plots depict percentage of total cells. B: Cumulative data depicting CD4 Tfh cells, with a dot representing one animal. $P$ values are determined by one-way analysis of variance with Tukey's multiple comparison test. Data are expressed as means \pm SEM of each experimental group (B). ${ }^{*} P<0.05,{ }^{*} P<0.01$, and ${ }^{* *} P<0.001$.

idiotype-positive IgG2a as well as glomerular changes based on electron microscopic studies consistent with mesangioproliferative glomerulonephritis. ${ }^{5}$ In our study of the mice listed in Table 3, 13 had minimal low-grade glomerulonephritis and two had mild but still low-grade changes (Table 3 and Supplemental Figure S1, E and F). No mice observed for up to 16 months had end-stage renal disease. Taken together, these studies showed that $564^{+/+}$mice were highly susceptible to the development of hematopoietic neoplasms and bacterial infections but had only mild renal disease.

\section{Immune Cell Distributions in 564Igi Mice}

The focus of previous studies of hematopoietic cells in $564^{+/-}$mice was on B cells and, to a lesser extent, myeloid cells. $^{5,35}$ Other studies of mice with TLR7-driven autoimmune diseases, including BXSB.Yaa mice, ${ }^{7,36}$ TLR7 transgenics, ${ }^{8}$ or SJL/J mice with lymphoproliferation and lymphoma ${ }^{17}$ showed that they have increased frequencies of total $\mathrm{CD}^{+}$and $\mathrm{CD}^{+} \mathrm{T}$ cells as well as $\mathrm{CD} 4^{+} \mathrm{T}$ follicular helper cells (Tfh) that secrete high levels of IL-21. To determine whether alterations in Tfh frequencies and IL21 expression also characterized the disease of $564^{+/+}$ mice, we first performed FACS analyses of spleens from $564^{+/+}$mice. This showed that they had higher frequencies of Tfh cells than spleens of control B6 mice at all ages tested and that the total numbers of $\mathrm{Tfh}$, defined as $\mathrm{CD} 4{ }^{+}$inducible $\mathrm{T}$ cell co-stimulator $(\mathrm{ICOS})^{\mathrm{hi}} \mathrm{CXCR} 5^{+-}$ programmed cell death protein (PD)- $1^{+}$(Figure 2, A and B, and Supplemental Figure S2), increased progressively from 4 to 8 months of age, for both sexes (Figure 2B). This contrasts with the well-described sex-related differences in hematopoietic cell distributions between BXSB.Yaa male and female mice that result from a doubling of $T l r 7$ copy number in males. ${ }^{13,37}$ 
A

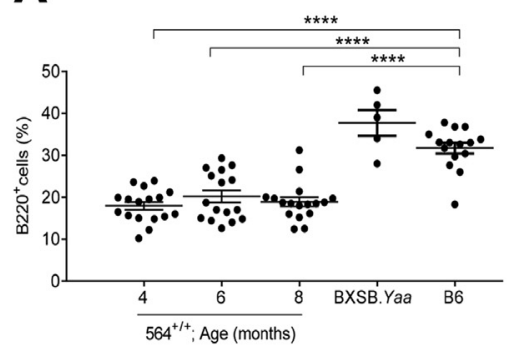

D

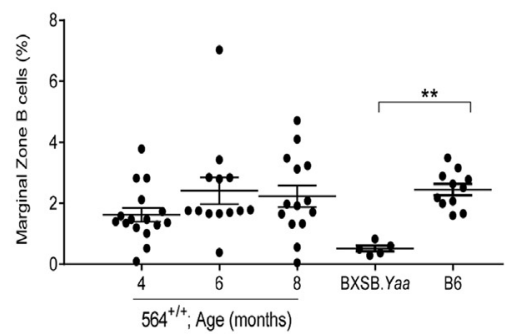

B

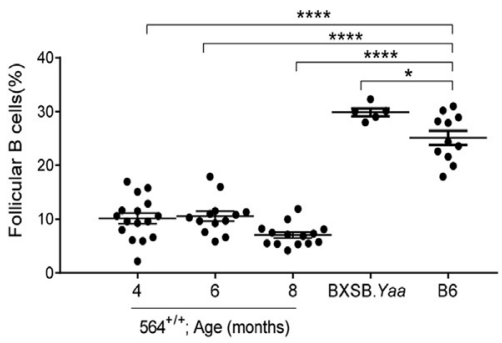

E

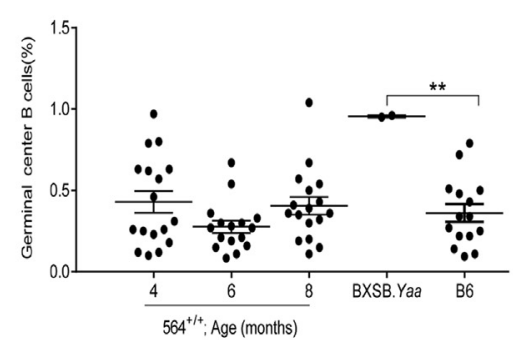

C

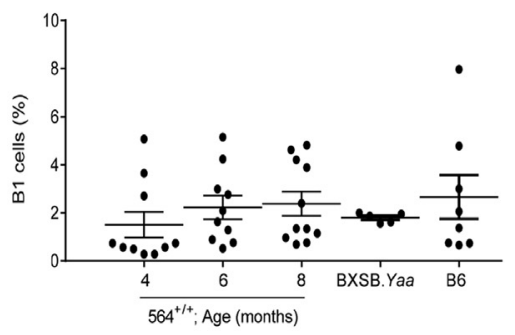

$\mathbf{F}$

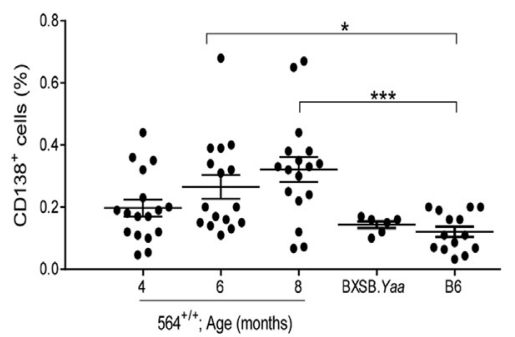

Figure 3 Immune cell distribution in spleens of $564^{+/+}$mice. Spleen cell suspensions from $564^{+/+}$( 4 to 8 months), BXSB.Yaa (4 months), and B6 (4 months) mice were stained for different cell populations and analyzed by multicolor flow cytometry. Live single cells were gated and analyzed for $B$ cells $\left(\mathrm{B} 220^{+} ; \mathrm{A}\right)$, follicular B cells $\left(\mathrm{B} 220^{+} \mathrm{CD}^{-} \mathrm{CD}^{2} 3^{\mathrm{hi}} \mathrm{CD} 21^{\mathrm{lo} /-} ; \mathrm{B}\right)$, B1B cells $\left(\mathrm{B} 220^{+} \mathrm{CD}^{+} ; \mathrm{C}\right)$, marginal zone $\mathrm{B}$ cells $\left(\mathrm{B} 220^{+} \mathrm{CD} 5^{-} \mathrm{CD} 23^{\mathrm{lo} /-} \mathrm{CD} 21^{\mathrm{hi}} ; \mathrm{D}\right)$, germinal center

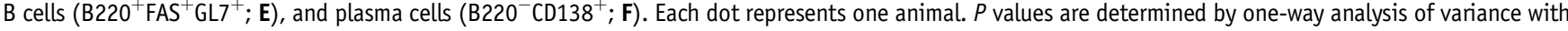
Tukey's multiple comparison test. Data are expressed as means \pm SEM. ${ }^{*} P<0.05,{ }^{* *} P<0.01,{ }^{* * *} P<0.001$, and ${ }^{* * * * P}<0.0001$.

Additional analyses of spleen cells from $564^{+/+}$mice showed that the frequencies and numbers of total B cells and of follicular B cells were lower than for B6 mice at all ages tested (Figure 3, A and B, and Supplemental Figure S3A), similar to results reported previously for $564^{+/-}$mice. ${ }^{5}$ Previous studies of $564^{+/-}$mice failed to detect any idiotype-positive B-1 cells, and total B-1 cell numbers were not described. ${ }^{5} \mathrm{We}$ found that the frequencies of total B-1 cells, defined as $\mathrm{CD} 19^{+} \mathrm{IgM}^{+} \mathrm{CD}^{+} \mathrm{B} 220^{-}$, in spleens of $564^{+/+}$mice were similar to those of B6 mice at all time points (Figure 3C and Supplemental Figure S3A). In addition, the frequencies of total $\mathrm{B}$ cells and follicular $\mathrm{B}$ cells $\left(\mathrm{B} 220^{+} \mathrm{CD} 5^{-} \mathrm{CD} 23^{\mathrm{hi}} \mathrm{CD} 21^{\mathrm{lo} /-}\right)$ (Supplemental Figure S3B) were similar between the different age groups of $564^{+/+}$mice, irrespective of sex, although they were significantly lower than in B6 controls. Interestingly, the total numbers of splenic marginal zone $\mathrm{B}$ cells $\left(\mathrm{CD} 19^{+} \mathrm{CD} 21^{\mathrm{hi}} \mathrm{CD} 23^{-}\right)$did not differ significantly at any age from levels in spleens of normal B6 mice (Figure 3D and Supplemental Figure S3A).

In BXSB.Yaa male ${ }^{13}$ and SJL female mice, ${ }^{17}$ increased frequencies of $\mathrm{Tfh}$ were associated with increased frequencies of GC B cells and plasmablasts because of increased IL-21 signaling. Interestingly, the frequencies of GC B cells $\left(\mathrm{B} 220^{+} \mathrm{GL}^{+} \mathrm{Fas}^{+}\right)$in spleens of $564^{+/+}$mice did not differ from those of normal B6 mice at any of the ages examined (Figure 3E and Supplemental Figure S4). In contrast, the frequencies of splenic $\mathrm{CD} 138^{+}$plasmablasts/ plasma cells in spleens of $564^{+/+}$mice tended to be higher than for spleens of B6 mice at all time points tested
(Figure 3F and Supplemental Figure S4). Taken together, these data demonstrated that $564^{+/+}$mice have increased numbers of $\mathrm{Tfh}$ and plasmablasts/plasma cells without having increased frequencies of GC B cells. The high frequencies of plasma cells and plasmablasts seen without an increase in GC B cells could represent extrafollicular plasma cells that develop without GC passage. ${ }^{38}$

\section{Serological Studies}

Increased numbers of Tfh and plasmablasts are known to be associated with hypergammaglobulinemia, including increased levels of IgG2b and IgM. To determine whether the disease manifestations in $564^{+/+}$mice correlate with increased serum immunoglobulins, we collected serum samples from male and female $564^{+/+}$mice of different ages and quantified IgG2b, IgM, and IgG1 levels by sandwich enzyme-linked immunosorbent assay. The $564^{+/+}$ mice had higher IgG2b levels than B6 mice as early as 2 months of age, IgM by 4 to 6 months, and IgG1 at 6 months, with levels comparable to those of male BXSB.Yaa mice (Figure 4, A-C). Serum levels of IgG2b and IgM tended to increase with age in males, but were higher and stable with age in females, whereas levels of IgG1 were relatively stable over time for both sexes (Supplemental Figure S5).

We also quantified serum ANA and anti-dsDNA antibody levels in the same cohorts. The $564^{+/+}$mice had significantly higher levels of ANA and anti-dsDNA antibodies than B6 controls, levels that were even higher than those for 

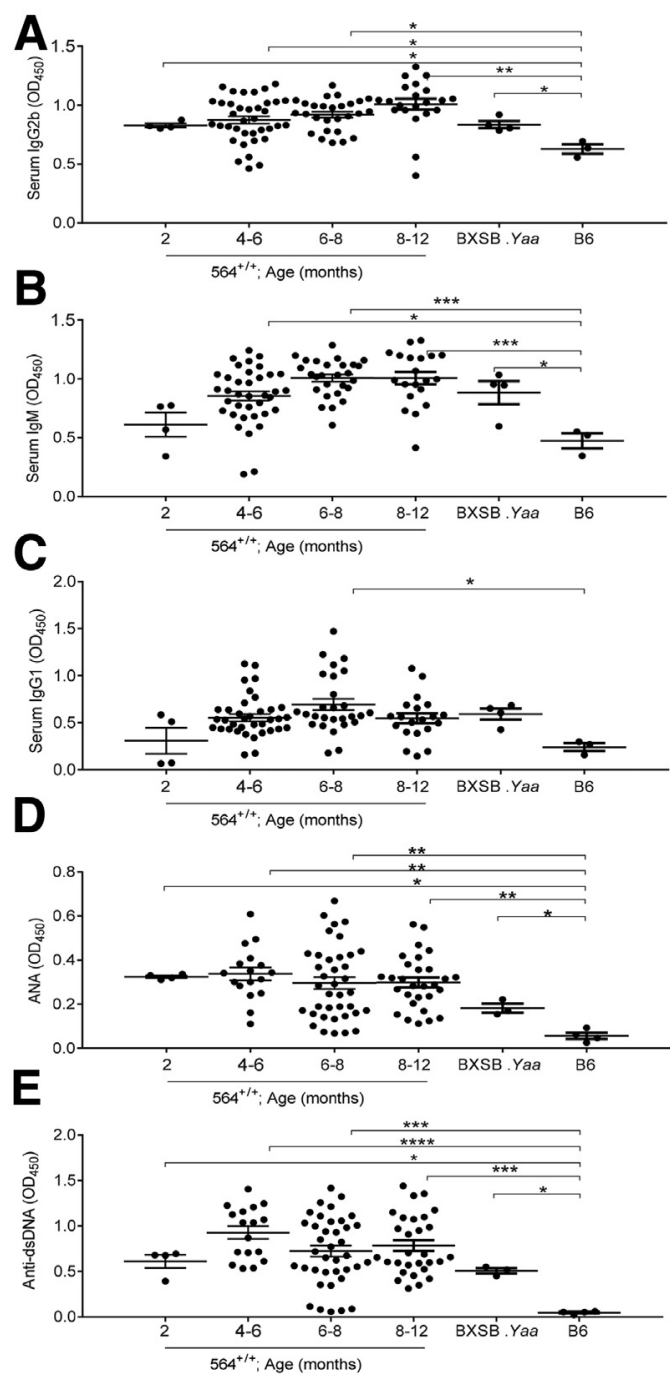

Figure 4 Serological analysis of $564^{+/+}$mice. Serum samples from $564^{+/+}$mice (2 to 12 months old), BXSB.Yaa mice (4 months old), and B6 mice (4 months old) were taken, and levels of IgG2b (A), IgM (B), IgG1 (C), ANA (D), and anti-dsDNA (E) were measured by sandwich enzyme-linked immunosorbent assay. Data are depicted as OD measured at $450 \mathrm{~nm}$. Each dot represents one mouse. Statistical analysis was performed using one-way analysis of variance with Tukey's multiple comparison test. Data are expressed as represented as means \pm SEM $(\mathbf{A}-\mathbf{E}) .{ }^{*} P<0.05$, ${ }^{* *} P<0.01,{ }^{* * *} P<0.001$, and ${ }^{* * * *} P<0.0001$.

male BXSB.Yaa mice (Figure 4, D and E). ANA antibodies in the absence of receptor editing must be high simply because of the nature of the 564 anti-RNA/single-stranded DNA antibody knockins. Previous studies of serum samples from $564^{+/-}$mice showed that they contained antibodies to single-stranded DNA but not to dsDNA. ${ }^{5}$ The high titers of anti-dsDNA are thus unanticipated and consequently striking. Taken together, these findings indicate that $564^{+/+}$mice exhibit serological manifestations of autoimmunity and immune activation by 6 to 8 months of age, irrespective of sex (Supplemental Figure S6). This again is distinct from the male/female differences characteristic of BXSB mice.
Gene Expression Profiling of Spleens from Aging $564^{+/+}$Mice

To develop molecular understandings of genes that might contribute to the pathogenesis of disease in $564^{+/+}$mice, we performed microarray-based gene expression profiling of spleens from 4-month-old B6 controls and $564^{+/+}$mice at 4, 8 , and 12 months of age. A principal component analysis of the four groups showed that they fell into distinct nonoverlapping clusters, with each of the $564^{+/+}$age groups being more closely related to one another than the B6 controls (Figure 5A). A one-way analysis of variance was used to identify the sources of variation among these groups, with the mean $\mathrm{F}$ ratio calculated by one-way analysis of variance. Genotype was identified as the greatest source of variation, with age being much less influential (Figure 5B).

A one-way analysis of variance $(P<0.05)$ of the four groups was used to identify differentially expressed genes with a fold change $>1.2$ in at least one comparison of six combinations $\left(564^{+/+} 4\right.$ months versus $\mathrm{B} 6 ; 564^{+/+}$ 8 months versus B6; $564^{+/+} 12$ months versus B6; $564^{+/+}$ 8 months versus $564^{+/+} 4$ months; $564^{+/+} 12$ months versus $564^{+/+} 4$ months; and $564^{+/+} 12$ months versus $564^{+/+}$ 8 months). This analysis yielded 887 known or predicted genes (Supplemental Table S1). Of these genes, 267 were up-regulated in spleens of 4 months $564^{+/+}$versus B6 mice, many of which were also found to be up-regulated in comparisons of 8 - and 12-month-old $564^{+/+}$versus 4month-old B6 mice. More important, these genes included $I l 21$, which is expressed at high levels and drives disease in several mouse models of autoimmunity ${ }^{13,15}$ as well as lymphomagenesis in SJL mice. ${ }^{17} \mathrm{IL}-21$ protein is known to regulate the expression of key immunomodulators. Consistent with previous findings, we found that increases in the transcript levels of IL-21 were associated with decreased expression of $I l 7 r^{39}$ and increases in $I l 10,^{39-41} P d 1,{ }^{42}$ Mmp $9,{ }^{43}$ and $P r d m l .{ }^{24}$ The most striking aspect of genes with reduced expression in the $564^{+/+}$mice was that few had reduced expression at all three time points examined.

We then used Fisher's exact test to identify significantly enriched biological categories using Ingenuity Pathway Analysis. The top five categories included hematological system development and function as well as immune cell trafficking and humoral immune responses (Figure 5D). An analysis of significant genes in humoral responses based on $P$ values from the analysis of variance included a large series previously associated with late stages of B-cell maturation, including (in addition to $I l 21$ ) Prdml (B lymphocyteinduced maturation protein), $S d c 1$ (syndecan), Tnfrsfl7 (B cell maturation antigen), Igj (J chain), Ill3ra2, Il4, and $I l 10$ as well as BCR signaling, Pdcdl, and T-B cell signaling, Faslg, and Tnfrsf9. A network analysis with Ingenuity Pathway Analysis algorithms presented the predicted functions of quantity of plasma cells and quantity of $\operatorname{IgG} 2 \mathrm{~b}$ to be activated, whereas proliferation of B lymphocytes was inhibited in $564^{+/+}$mice (Figure 5C). These results are in 
A

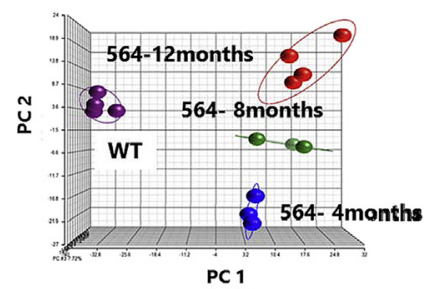

D

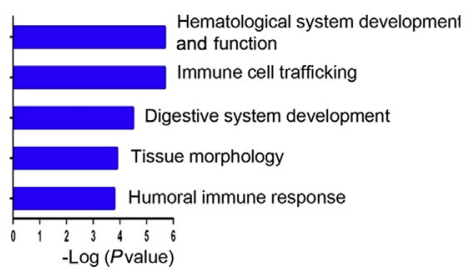

B

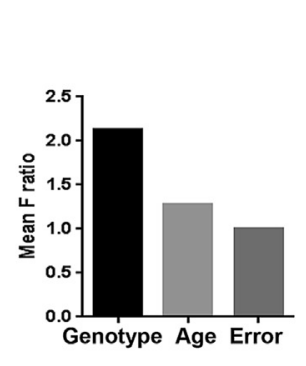

C

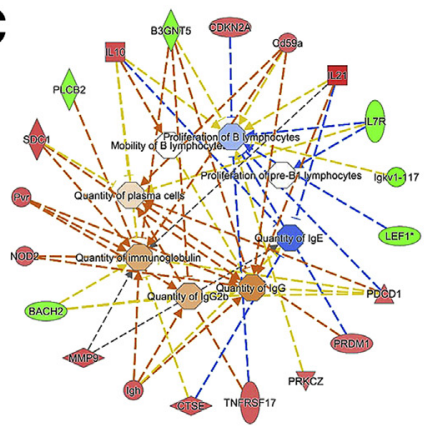

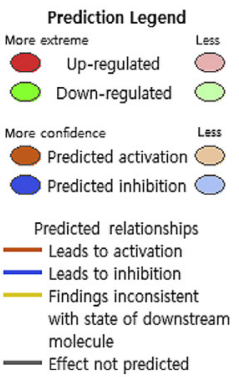

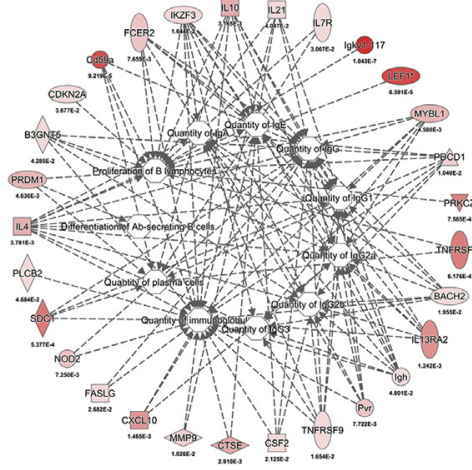

Figure 5 Transcriptome analysis of spleens from $564^{+/+}$ mice. Total RNAs from 4-, 8-, and 12-month-old $564^{+/+}$mice and $\mathrm{B} 6$ mice were examined for gene expression profiles with biological replications of three to four mice per group. A: Plot from principle component analysis is shown. Each ball represents an individual mouse. B: Source of variations in oneway analysis of variance. Differentially expressed genes were categorized based on their biological functions, and the enrichments were tested for statistical significance by Fisher's exact test. C: The top five significant categories. Members in the humoral immune response shown $(\mathbf{C})$ are displayed in the network, and activities of detailed biological processes were predicted for activation or inhibition using Ingenuity Pathway Analysis algorithms (D).

good accordance with our observations on immune cell distribution (Figure 3) and serological studies (Figure 4) and are consistent with previous demonstrations of B-cell activation resulting in hypergammaglobulinemia and hypersensitivity to BCR ligation in $564^{+/-}$mice..$^{5}$

\section{Antibiotic Effects}

The findings of enhanced susceptibility to infections, including peritoneal and liver abscesses and pneumonia, prompted us to determine whether depletion of the intestinal flora with antibiotics would affect this phenotype or those of autoimmunity and lymphomagenesis. To test this, $564^{+/+}$mice were maintained on water supplemented with vancomycin, ampicillin, metronidazole, and neomycin, beginning with treatment of pregnant females. Perhaps predictably, none of the mice observed through 13 months of age developed any abscesses or pneumonia. Unexpectedly, however, none of the mice exhibited visible lymphadenopathy or splenomegaly or became moribund with lymphomas. Histological studies of tissues obtained at necropsy at the end of treatment were also negative for lymphomas or infections. Serological studies of treated $564^{+/+}$ mice showed that they had reduced levels of serum $\operatorname{IgM}, \operatorname{IgG} 2 b$, anti-dsDNA, and ANA antibodies (Figure 6, A and B). These results indicated that the intestinal flora had profound effects on the phenotypes of susceptibility to infection, autoimmunity, and lymphoma exhibited by $564^{+/+}$mice.

We also analyzed immune cell distributions in spleens of $564^{+/+}$mice treated with vancomycin, ampicillin, metronidazole, and neomycin water compared with untreated $564^{+/+}$ and B6 mice. The mice treated with antibiotics had increased frequencies of CD4 $\mathrm{T}$ cells (Figure 7A) with a less activated phenotype, as seen by reduced expression of CD44 (Figure 7B) and CD69 (not depicted) compared to cells from untreated mice. In addition, the percentages of $\mathrm{Tfh}$ $\left(\mathrm{CD}^{+}{ }^{+} \mathrm{ICOS}^{+} \mathrm{PD}^{+} \mathrm{CXCR}^{+}\right)$cells in antibiotic-treated $564^{+/+}$mice were reduced compared to untreated $564^{+/+}$ mice, although not significantly (Figure $7 \mathrm{C}$ and Supplemental Figure S7).

We also assessed B-cell numbers and activation status in $564^{+/+}$mice treated with antibiotics and found that the total numbers of germinal center B cells and plasma cells were significantly reduced, although their frequencies were comparable to those of B6 mice (Figure 8A). In addition, we also observed that the activation phenotype of B cells from antibiotic-treated $564^{+/+}$mice was significantly reduced, as evidenced by expression of CD86, CD80, major histocompatibility complex II, and CD40 (Figure 8B). Despite these differences, we did not notice any changes in the frequencies of follicular or marginal zone B cells in antibiotic-treated $564^{+/+}$mice (Supplemental Figure S8, A and B), although the frequencies of transitional $\mathrm{B}$ cells were reduced and were comparable to healthy B6 controls. This reinforces the finding that transitional B cells accumulate in lupus mice, leading to autoantibody production. ${ }^{44}$

The important influences of gut microbiota on lymphoma development documented herein prompted us to reexamine intestinal histology of untreated mice to see if they might be the source of lymphomas. Aside from what appeared to be 

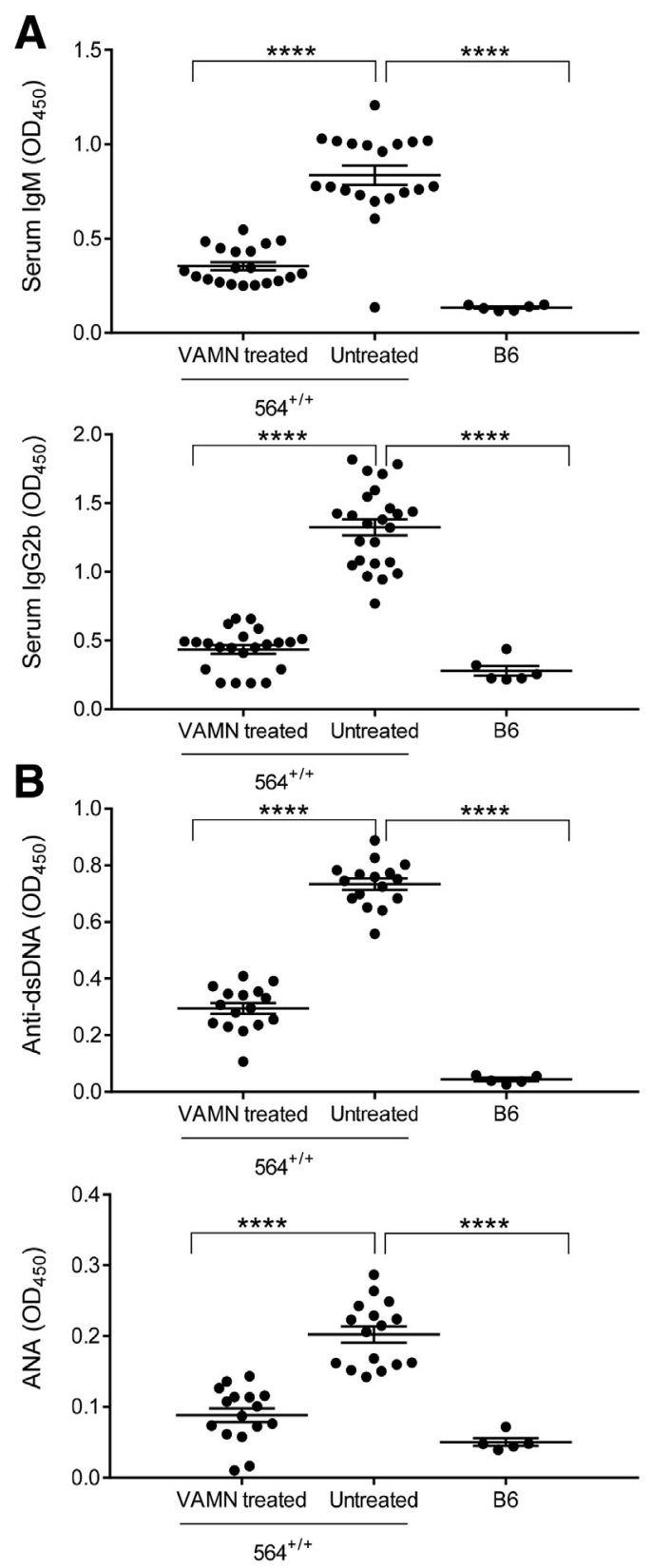

Figure 6 Serological changes on antibiotic treatment in $564^{+/+}$mice. The $564^{+/+}$mice were maintained continuously on water supplemented with vancomycin, ampicillin, metronidazole, and neomycin (VAMN water). Serum samples were collected from 6- to 8-month-old VAMN-treated mice and quantified for levels of IgM and IgG2b (A) and anti-dsDNA and ANA (B). Comparisons were made with age-matched untreated $564^{+/+}$and $B 6$ control mice. Each dot represents one animal. Statistical analysis was performed by one-way analysis of variance with Tukey's multiple comparison test. Data are expressed as represented as means \pm SEM $(\mathbf{A}$ and $\mathbf{B})$. ${ }^{* * * *} P<0.0001$.

metastatic spread of splenic tumors to Peyer's patches and the rare detection of parasites (Table 3), there was no evidence of prelymphomatous changes in the guts of 13 4.5-month-old mice.

Taken together, our findings indicate that antibiotic treatment of $564^{+/+}$mice had a profound effect in determining the onset and progression of autoimmunity and that treated mice exhibited significantly reduced disease manifestations of lymphoma and susceptibility to infection as well as parameters of immune activation.

\section{Discussion}

The results of this study demonstrated that mice homozygous for knockins of the heavy and light chains of the autoreactive 564 BCR $\left(564^{+/+}\right.$mice) developed a complex phenotype involving autoimmunity, lymphoma, and susceptibility to bacterial infections. Previous analyses of mice heterozygous for knockins at both loci $\left(564^{+/-}\right.$mice) showed that they shared a number of autoimmune features with other genetically engineered mice expressing BCRs reactive with nucleic acids ${ }^{5}$ but did not develop lymphomas or infectious diseases. Remarkably, $564^{+/+}$mice with antibiotic-mediated depletion of gut flora had reduced signs of autoimmunity and developed neither lymphomas nor infections.

Dissecting the influences responsible for driving the development of these three phenotypes in $564^{+/+}$mice is complicated by the following: complex interactions of gut microbiota with the immune systems of mice and humans, ${ }^{45}$ including the importance of commensal microbiota to the development of autoimmune diseases ${ }^{46,47}$ and the associations between autoimmune diseases and the development of lymphomas. ${ }^{26}$ The effects of microbiota on development of different $\mathrm{CD}^{+}{ }^{+} \mathrm{T}$-cell subsets can promote autoimmune diseases by driving Th17 differentiation or be inhibitory by enhancing $\mathrm{T}$ regulatory cell expansion; these are other examples of important interactions. For some human lymphomas, infectious agents might be directly responsible for driving tumor development. Several different lymphomas of MALT involving the stomach, eye, and small intestine have been associated with infections by Helicobacter pylori, Chlamydophilia psittaci, and Camplobacter jejuni, respectively, that in some cases can be cured by administration of antibiotics. $^{48-50}$

Our studies suggest that effects on autoimmune disease as well as lymphomas might be driven by expansion of $\mathrm{Tfh}$ and expression of their signature cytokine, IL-21. The contributions of IL-21 to autoimmunity are well documented in studies of BXSB.Yaa, TLR7 transgenic, and nonobese diabetic mice and are suggested by studies of SLE, Sjögren syndrome, and highly active rheumatoid arthritis in humans. ${ }^{13,15,17,20,26}$

The finding that $564^{+/+}$mice express high levels of IL-21 suggests parallels to SJL disease characterized by highly penetrant development of mature B-cell lineage neoplasms between 6 and 12 months of age. We recently showed that lymphoma development in this strain is highly IL-21 dependent as no tumors developed in mice bearing a null allele of the IL-21 receptor up to a year of age ${ }^{17}$ In addition, IL-21 is also known to be a potent stimulus for plasma cell differentiation and immunoglobulin secretion, ${ }^{51}$ and gene expression profiling of spleens from $564^{+/+}$mice 
A

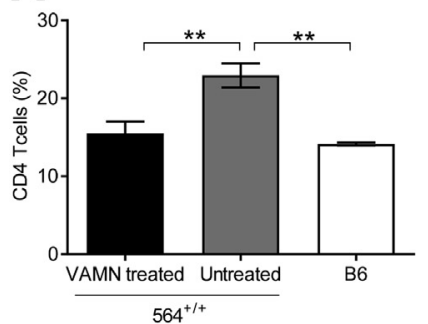

B

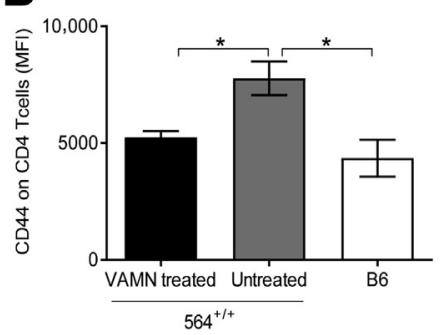

C

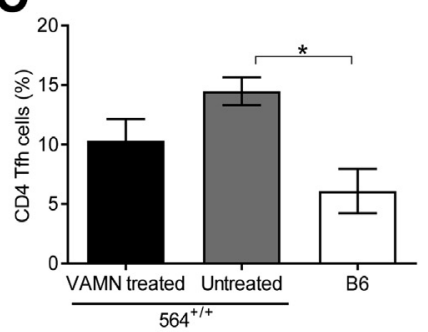

Figure 7 Changes in T-cell profile on antibiotic treatment in $564^{+/+}$mice. Splenocytes from vancomycin, ampicillin, metronidazole, and neomycin (VAMN)-treated $564^{+/+}$, untreated $564^{+/+}$, and B6 control mice were stained with antibodies against CD3, CD4, CD44, CD69, ICOS, CXCR5, and PD-1 and analyzed by flow cytometry. A: Total percentages of CD4 cells. B: CD44 expression on CD4 cells is determined as mean fluorescence intensity (MFI). C: Total percentages of $\mathrm{CD} 4 \mathrm{Tfh}\left(\mathrm{CD}^{+}{ }^{+} \mathrm{ICSS}^{+} \mathrm{CXCR}^{+} \mathrm{PD}^{+}\right)$cells. Statistical analysis was performed using one-way analysis of variance with Tukey's multiple comparison test. Data are expressed as means $\pm \operatorname{SEM}(\mathbf{A}-\mathbf{C}) .{ }^{*} P<0.05,{ }^{* *} P<0.01$.

demonstrated enhanced expression of a large number of genes involved in both of these processes. It would be interesting in the future to directly examine a possible role for Tfh in $564^{+/+}$mice by introducing a null allele of the IL21 receptor onto the $564^{+/+}$genetic background.

During the past decade, SLE, Sjögren syndrome, and rheumatoid arthritis have been associated with significantly increased risk for development of non-Hodgkin lymphomas. ${ }^{25-28}$ A number of autoimmune/inflammatory conditions in mice have also been associated with increased incidences of lymphoma. Chronic lymphocytic leukemialike neoplasms occur in New Zealand black-related strains, ${ }^{52,53}$ and DLBCL and anaplastic plasmacytomas occur in mice bearing Fasl or Fas mutations. ${ }^{54,55}$ In the case
A

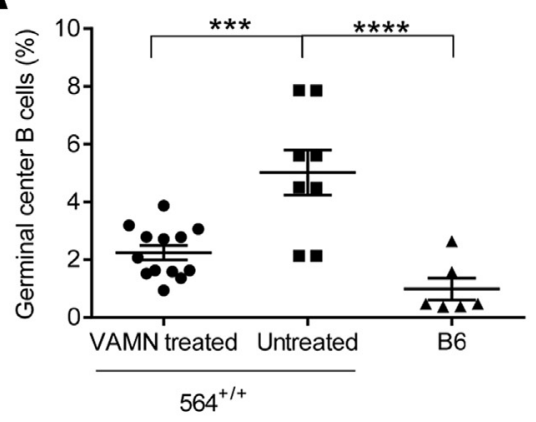

B
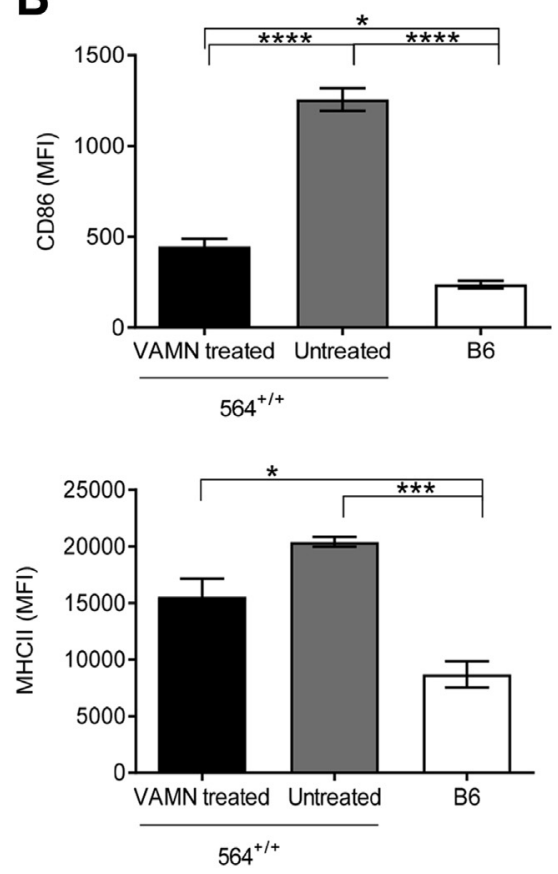
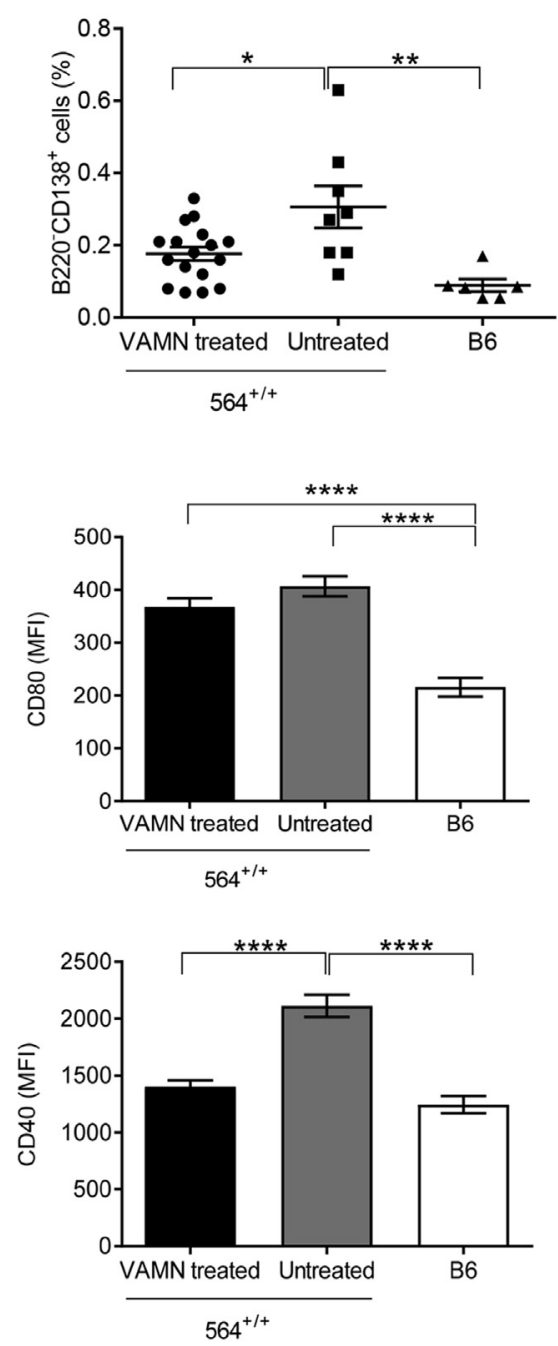

Figure 8 Changes in B-cell profile in vancomycin, ampicillin, metronidazole, and neomycin (VAMN) - treated $564^{+/+}$mice. Splenocytes from VAMN-treated 6-month-old $564^{+/+}$, untreated $564^{+/+}$, and B6 control mice were stained with antibodies against B220, CD138, GL7, FAS, CD80, CD86, major histocompatibility complex (MHC) II, and CD40, and analyzed by flow cytometry. A: Total percentages of germinal center $B$ cells $\left(\mathrm{B}^{2} 20^{+} \mathrm{FAS}^{+} \mathrm{GL7}^{+}\right.$) and plasma cells (B220 ${ }^{-}$CD138 ${ }^{+}$). B: Expression of CD86, CD80, MHCII, and $\mathrm{CD} 40$ on $\mathrm{B}_{2} 2 \mathrm{O}^{+}$cells is shown as mean fluorescence intensity (MFI). Statistical analysis was performed using one-way analysis of variance with Tukey's multiple comparison test. Data are expressed as means \pm SEM (A and $\mathbf{B}) .{ }^{*} P<0.05$, ${ }^{* *} P<0.01,{ }^{* *} P<0.001$, and ${ }^{* * * *} P<0.0001$. 
of $564^{+/+}$mice, it is difficult to tell to what extent tumor susceptibility can be attributed to the low-grade autoimmunity exhibited by this strain and how much might be secondary to related infectious diseases or inflammation. More important, however, only two mice had coexisting infections and lymphomas, indicating that there is not a direct tie between lymphoma induction and parenchymal bacterial infections and that gut microbiota are most likely responsible. The striking effect of antibiotic-mediated depletion of gut microbiota on tumor development raised the possibility that the lymphomas might originate in the gut. This was discounted by histological studies of intestinal tissues from normal $564^{+/+}$mice that revealed no evidence of primary lesions, although there was lymphomatous infiltration in Peyer's patches of one case that was characterized by massive splenic and nodal involvement. Nonetheless, it is abundantly clear that intestinal microbiota represent a major stimulus to development of lymphomas as well as some manifestations of autoimmunity.

\section{Acknowledgments}

S.J., D.-M.S., H.W., Z.N., and A.L.K. performed experiments and generated and interpreted data; J.M.W. and H.C.M. performed histopathological studies and interpreted data; S.J. and H.C.M. designed the studies; S.J. and H.C.M. drafted the manuscript; and all authors contributed to revisions and approved the final version of the manuscript.

\section{Supplemental Data}

Supplemental material for this article can be found at http://dx.doi.org/10.1016/j.ajpath.2017.05.017.

\section{References}

1. Fields ML, Erikson J: The regulation of lupus-associated autoantibodies: immunoglobulin transgenic models. Curr Opin Immunol 2003, 15:709-717

2. Gavalchin J, Seder RA, Datta SK: The NZB X SWR model of lupus nephritis, I: cross-reactive idiotypes of monoclonal anti-DNA antibodies in relation to antigenic specificity, charge, and allotype: identification of interconnected idiotype families inherited from the normal SWR and the autoimmune NZB parents. J Immunol 1987, 138: $128-137$

3. Mohan C, Adams S, Stanik V, Datta SK: Nucleosome: a major immunogen for pathogenic autoantibody-inducing $\mathrm{T}$ cells of lupus. J Exp Med 1993, 177:1367-1381

4. Vlahakos DV, Foster MH, Adams S, Katz M, Ucci AA, Barrett KJ, Datta SK, Madaio MP: Anti-DNA antibodies form immune deposits at distinct glomerular and vascular sites. Kidney Int 1992, 41:1690-1700

5. Berland R, Fernandez L, Kari E, Han JH, Lomakin I, Akira S, Wortis HH, Kearney JF, Ucci AA, Imanishi-Kari T: Toll-like receptor 7-dependent loss of B cell tolerance in pathogenic autoantibody knockin mice. Immunity 2006, 25:429-440

6. Fairhurst AM, Hwang SH, Wang A, Tian XH, Boudreaux C, Zhou XJ, Casco J, Li QZ, Connolly JE, Wakeland EK: Yaa autoimmune phenotypes are conferred by overexpression of TLR7. Eur J Immunol 2008, 38:1971-1978
7. Pisitkun P, Deane JA, Difilippantonio MJ, Tarasenko T, Satterthwaite AB, Bolland S: Autoreactive B cell responses to RNArelated antigens due to TLR7 gene duplication. Science 2006, 312: 1669-1672

8. Deane JA, Pisitkun P, Barrett RS, Feigenbaum L, Town T, Ward JM, Flavell RA, Bolland S: Control of toll-like receptor 7 expression is essential to restrict autoimmunity and dendritic cell proliferation. Immunity 2007, 27:801-810

9. Walsh ER, Pisitkun P, Voynova E, Deane JA, Scott BL, Caspi RR, Bolland $\mathrm{S}$ : Dual signaling by innate and adaptive immune receptors is required for TLR7-induced B-cell-mediated autoimmunity. Proc Natl Acad Sci U S A 2012, 109:16276-16281

10. Barrat FJ, Meeker T, Chan JH, Guiducci C, Coffman RL: Treatment of lupus-prone mice with a dual inhibitor of TLR7 and TLR9 leads to reduction of autoantibody production and amelioration of disease symptoms. Eur J Immunol 2007, 37:3582-3586

11. Hughes T, Kim-Howard X, Kelly JA, Kaufman KM, Langefeld CD, Ziegler J, Sanchez E, Kimberly RP, Edberg JC, Ramsey-Goldman R, Petri M, Reveille JD, Martin J, Brown EE, Vila LM, Alarcon GS, James JA, Gilkeson GS, Moser KL, Gaffney PM, Merrill JT, Vyse TJ, Alarcon-Riquelme ME, Network B, Nath SK, Harley JB, Sawalha AH: Fine-mapping and transethnic genotyping establish IL2/IL21 genetic association with lupus and localize this genetic effect to IL21. Arthritis Rheum 2011, 63:1689-1697

12. Tian J, Ma Y, Li J, Cen H, Wang DG, Feng CC, Li RJ, Leng RX, Pan HF, Ye DQ: The TLR7 7926A $>$ G polymorphism is associated with susceptibility to systemic lupus erythematosus. Mol Med Rep 2012, 6:105-110

13. Bubier JA, Sproule TJ, Foreman O, Spolski R, Shaffer DJ, Morse HC 3rd, Leonard WJ, Roopenian DC: A critical role for IL-21 receptor signaling in the pathogenesis of systemic lupus erythematosus in BXSB-Yaa mice. Proc Natl Acad Sci U S A 2009, 106:1518-1523

14. Spolski R, Kashyap M, Robinson C, Yu Z, Leonard WJ: IL-21 signaling is critical for the development of type I diabetes in the NOD mouse. Proc Natl Acad Sci U S A 2008, 105:14028-14033

15. Wang L, Yu CR, Kim HP, Liao W, Telford WG, Egwuagu CE, Leonard WJ: Key role for IL-21 in experimental autoimmune uveitis. Proc Natl Acad Sci U S A 2011, 108:9542-9547

16. Young DA, Hegen M, Ma HL, Whitters MJ, Albert LM, Lowe L, Senices M, Wu PW, Sibley B, Leathurby Y, Brown TP, NickersonNutter C, Keith JC Jr, Collins M: Blockade of the interleukin21/interleukin-21 receptor pathway ameliorates disease in animal models of rheumatoid arthritis. Arthritis Rheum 2007, 56:1152-1163

17. Jain S, Chen J, Nicolae A, Wang H, Shin DM, Adkins EB, Sproule TJ, Leeth CM, Sakai T, Kovalchuk AL, Raffeld M, Ward JM, Rehg JE, Waldmann TA, Jaffe ES, Roopenian DC, Morse HC 3rd: IL-21-driven neoplasms in SJL mice mimic some key features of human angioimmunoblastic T-cell lymphoma. Am J Pathol 2015, 185:3102-3114

18. Ahearne MJ, Allchin RL, Fox CP, Wagner SD: Follicular helper T-cells: expanding roles in T-cell lymphoma and targets for treatment. Br J Haematol 2014, 166:326-335

19. Lamprecht B, Kreher S, Anagnostopoulos I, Johrens K, Monteleone G, Jundt F, Stein H, Janz M, Dorken B, Mathas S: Aberrant expression of the Th2 cytokine IL-21 in Hodgkin lymphoma cells regulates STAT3 signaling and attracts Treg cells via regulation of MIP-3alpha. Blood 2008, 112:3339-3347

20. Scheeren FA, Diehl SA, Smit LA, Beaumont T, Naspetti M, Bende RJ, Blom B, Karube K, Ohshima K, van Noesel CJ, Spits H: IL-21 is expressed in Hodgkin lymphoma and activates STAT5: evidence that activated STAT5 is required for Hodgkin lymphomagenesis. Blood 2008, 111:4706-4715

21. Brenne AT, Ro TB, Waage A, Sundan A, Borset M, HjorthHansen H: Interleukin-21 is a growth and survival factor for human myeloma cells. Blood 2002, 99:3756-3762

22. Mehtap O, Atesoglu EB, Tarkun P, Hacihanefioglu A, Dolasik I, Musul MM: IL-21 and other serum proinflammatory cytokine levels 
in patients with multiple myeloma at diagnosis. J Postgrad Med 2014, 60:141-144

23. Ahearne MJ, Willimott S, Pinon L, Kennedy DB, Miall F, Dyer MJ, Wagner SD: Enhancement of CD154/IL4 proliferation by the T follicular helper (Tfh) cytokine, IL21 and increased numbers of circulating cells resembling $\mathrm{Tfh}$ cells in chronic lymphocytic leukaemia. Br J Haematol 2013, 162:360-370

24. Hodge LS, Ziesmer SC, Yang ZZ, Secreto FJ, Gertz MA, Novak AJ, Ansell SM: IL-21 in the bone marrow microenvironment contributes to IgM secretion and proliferation of malignant cells in Waldenstrom macroglobulinemia. Blood 2012, 120:3774-3782

25. Mackay IR, Rose NR: Autoimmunity and lymphoma: tribulations of B cells. Nat Immunol 2001, 2:793-795

26. Dias C, Isenberg DA: Susceptibility of patients with rheumatic diseases to B-cell non-Hodgkin lymphoma. Nat Rev Rheumatol 2011, 7: $360-368$

27. Goldin LR, Landgren O: Autoimmunity and lymphomagenesis. Int J Cancer 2009, 124:1497-1502

28. Zintzaras E, Voulgarelis M, Moutsopoulos HM: The risk of lymphoma development in autoimmune diseases: a meta-analysis. Arch Intern Med 2005, 165:2337-2344

29. Kogan SC, Ward JM, Anver MR, Berman JJ, Brayton C, Cardiff RD, Carter JS, de Coronado S, Downing JR, Fredrickson TN, Haines DC, Harris AW, Harris NL, Hiai H, Jaffe ES, MacLennan IC, Pandolfi PP, Pattengale PK, Perkins AS, Simpson RM, Tuttle MS, Wong JF, Morse HC 3rd; Hematopathology Subcommittee of the Mouse Models of Human Cancers Consortium: Bethesda proposals for classification of nonlymphoid hematopoietic neoplasms in mice. Blood 2002, 100:238-245

30. Morse HC 3rd, Anver MR, Fredrickson TN, Haines DC, Harris AW, Harris NL, Jaffe ES, Kogan SC, MacLennan IC, Pattengale PK, Ward JM; Hematopathology Subcommittee of the Mouse Models of Human Cancers Consortium: Bethesda proposals for classification of lymphoid neoplasms in mice. Blood 2002, 100: $246-258$

31. Ward JM, Rehg JE, Morse HC 3rd: Differentiation of rodent immune and hematopoietic system reactive lesions from neoplasias. Toxicol Pathol 2012, 40:425-434

32. Kovalchuk AL, duBois W, Mushinski E, McNeil NE, Hirt C, Qi CF, Li Z, Janz S, Honjo T, Muramatsu M, Ried T, Behrens T, Potter M: AID-deficient Bcl-xL transgenic mice develop delayed atypical plasma cell tumors with unusual Ig/Myc chromosomal rearrangements. J Exp Med 2007, 204:2989-3001

33. Shin DM, Shaffer DJ, Wang H, Roopenian DC, Morse HC 3rd: NOTCH is part of the transcriptional network regulating cell growth and survival in mouse plasmacytomas. Cancer Res 2008, 68:9202-9211

34. Shon WJ, Lee YK, Shin JH, Choi EY, Shin DM: Severity of DSSinduced colitis is reduced in Ido1-deficient mice with downregulation of TLR-MyD88-NF-kB transcriptional networks. Sci Rep 2015, 5:17305

35. Heesters BA, Das A, Chatterjee P, Carroll MC: Do follicular dendritic cells regulate lupus-specific B cells? Mol Immunol 2014, 62:283-288

36. Bubier JA, Bennett SM, Sproule TJ, Lyons BL, Olland S, Young DA, Roopenian DC: Treatment of BXSB-Yaa mice with IL-21R-Fc fusion protein minimally attenuates systemic lupus erythematosus. Ann N Y Acad Sci 2007, 1110:590-601

37. McPhee CG, Bubier JA, Sproule TJ, Park G, Steinbuck MP, Schott WH, Christianson GJ, Morse HC 3rd, Roopenian DC: IL-21 is a double-edged sword in the systemic lupus erythematosus-like disease of BXSB.Yaa mice. J Immunol 2013, 191:4581-4588

38. MacLennan IC, Toellner KM, Cunningham AF, Serre K, Sze DM, Zuniga E, Cook MC, Vinuesa CG: Extrafollicular antibody responses. Immunol Rev 2003, 194:8-18
39. Allard EL, Hardy MP, Leignadier J, Marquis M, Rooney J, Lehoux D, Labrecque N: Overexpression of IL-21 promotes massive CD8+ memory $\mathrm{T}$ cell accumulation. Eur J Immunol 2007, 37 : 3069-3077

40. Lindner S, Dahlke K, Sontheimer K, Hagn M, Kaltenmeier C, Barth TF, Beyer T, Reister F, Fabricius D, Lotfi R, Lunov O, Nienhaus GU, Simmet T, Kreienberg R, Moller P, Schrezenmeier H, Jahrsdorfer B: Interleukin 21-induced granzyme B-expressing B cells infiltrate tumors and regulate T cells. Cancer Res 2013, 73:2468-2479

41. Yang X, Yang J, Chu Y, Xue Y, Xuan D, Zheng S, Zou H: T follicular helper cells and regulatory B cells dynamics in systemic lupus erythematosus. PLoS One 2014, 9:e88441

42. Kinter AL, Godbout EJ, McNally JP, Sereti I, Roby GA, O'Shea MA, Fauci AS: The common gamma-chain cytokines IL-2, IL-7, IL-15, and IL-21 induce the expression of programmed death-1 and its ligands. J Immunol 2008, 181:6738-6746

43. Caruso R, Fina D, Peluso I, Fantini MC, Tosti C, Del Vecchio Blanco G, Paoluzi OA, Caprioli F, Andrei F, Stolfi C, Romano M, Ricci V, MacDonald TT, Pallone F, Monteleone G: IL-21 is highly produced in Helicobacter pylori-infected gastric mucosa and promotes gelatinases synthesis. J Immunol 2007, 178:5957-5965

44. Giltiay NV, Chappell CP, Sun X, Kolhatkar N, Teal TH, Wiedeman AE, Kim J, Tanaka L, Buechler MB, Hamerman JA, Imanishi-Kari T, Clark EA, Elkon KB: Overexpression of TLR7 promotes cell-intrinsic expansion and autoantibody production by transitional T1 B cells. J Exp Med 2013, 210:2773-2789

45. Honda K, Littman DR: The microbiota in adaptive immune homeostasis and disease. Nature 2016, 535:75-84

46. Chervonsky AV: Influence of microbial environment on autoimmunity. Nat Immunol 2010, 11:28-35

47. Yurkovetskiy LA, Pickard JM, Chervonsky AV: Microbiota and autoimmunity: exploring new avenues. Cell Host Microbe 2015, 17 : 548-552

48. Ferreri AJ, Ponzoni M, Guidoboni M, Resti AG, Politi LS, Cortelazzo S, Demeter J, Zallio F, Palmas A, Muti G, Dognini GP, Pasini E, Lettini AA, Sacchetti F, De Conciliis C, Doglioni C, Dolcetti R: Bacteria-eradicating therapy with doxycycline in ocular adnexal MALT lymphoma: a multicenter prospective trial. J Natl Cancer Inst 2006, 98:1375-1382

49. Zucca E, Bertoni F, Roggero E, Cavalli F: The gastric marginal zone B-cell lymphoma of MALT type. Blood 2000, 96:410-419

50. Al-Saleem T, Al-Mondhiry H: Immunoproliferative small intestinal disease (IPSID): a model for mature B-cell neoplasms. Blood 2005, $105: 2274-2280$

51. Leonard WJ, Wan CK: IL-21 signaling in immunity. F1000Res 2016, 5:224-233

52. Stall AM, Farinas MC, Tarlinton DM, Lalor PA, Herzenberg LA, Strober S, Herzenberg LA: Ly-1 B-cell clones similar to human chronic lymphocytic leukemias routinely develop in older normal mice and young autoimmune (New Zealand Black-related) animals. Proc Natl Acad Sci U S A 1988, 85:7312-7316

53. Phillips JA, Mehta K, Fernandez C, Raveche ES: The NZB mouse as a model for chronic lymphocytic leukemia. Cancer Res 1992, 52:437-443

54. Zhang JQ, Okumura C, McCarty T, Shin MS, Mukhopadhyay P, Hori M, Torrey TA, Naghashfar Z, Zhou JX, Lee CH, Roopenian DC, Morse HC 3rd, Davidson WF: Evidence for selective transformation of autoreactive immature plasma cells in mice deficient in Fasl. J Exp Med 2004, 200:1467-1478

55. Morse HC 3rd, Roths JB, Davidson WF, Langdon WY, Fredrickson TN, Hartley JW: Abnormalities induced by the mutant gene, lpr: patterns of disease and expression of murine leukemia viruses in SJL/J mice homozygous and heterozygous for lpr. J Exp Med 1985, 161:602-616 